\title{
Excess mortality associated with alcohol consumption
}

\author{
Peter Anderson
}

\begin{abstract}
To estimate the excess mortality due to alcohol in England and Wales death rates specific to alcohol consumption that had been derived from five longitudinal studies were applied to the current population divided into categories of alcohol consumption. Because of the $J$ shaped relation between alcohol consumption and death the excess mortality used as a baseline was an alcohol consumption of 1-10 units/ week and an adjustment was made for the slight excess mortality of abstainers. The number of excess deaths was obtained by subtracting the number of deaths expected if all the population had the consumption of the lowest risk group; correction for the total observed mortality in the population was made. This resulted in an estimate of 28000 deaths each year in England and Wales as the excess mortality among people aged 15-74 associated with alcohol consumption.
\end{abstract}

Consumption of alcohol is associated with many types of physical harm, ' but death certificates rarely mention alcohol as a primary or secondary cause of death. Only two to three thousand death certificates a year in England and Wales refer to alcohol. Thus little is known about the excess mortality associated with alcohol consumption. This paper reviews current estimates of excess mortality associated with alcohol consumption and offers a means of calculating this estimate based on the methods used for the relation between cigarette smoking and death.

TABLE I-Population of

England and Wales by age and sex in 1984 (millions)

\begin{tabular}{lcc}
\hline Age (years) & Men & Women \\
\hline $15-34$ & $6 \cdot 48$ & $6 \cdot 22$ \\
$35-64$ & $8 \cdot 05$ & $8 \cdot 24$ \\
$65-74$ & $1 \cdot 74$ & $2 \cdot 32$ \\
\hline
\end{tabular}

TABLE III - Number of deaths in England and Wales in 1985

\begin{tabular}{lrr}
\hline Age (years) & \multicolumn{1}{c}{ Men } & Women \\
\hline $15-34$ & 6245 & 2872 \\
$35-64$ & 67529 & 40765 \\
$65-74$ & 83728 & 57813 \\
\hline
\end{tabular}

Oxfordshire Health Authority, Oxford OX3 9DZ

Peter Anderson, MRCGP, senior registrar in community medicine

Current estimates for the excess mortality associated with alcohol consumption in England and Wales range between 5000 and 40000 deaths a year. ${ }^{14}$ McDonnell and Maynard reported a yearly excess mortality of 5000-8000 associated with use of alcohol in England and Wales in the age group 25-84. ${ }^{4}$ This estimate was based on work by Holtermann and Birchell, who calculated the proportion of disease attributable to "alcoholism" as

$$
\left[\left(\mathrm{X}_{1}-\mathrm{X}_{2}\right) /\left(\mathrm{X}_{2} \times \mathrm{Y}_{2}\right)\right] \times \mathrm{Y}_{1} \times 100
$$

where $X_{1}$ is the prevalence of disease among alcoholics, $\mathrm{X}_{2}$ is the prevalence of disease among the whole population, $Y_{1}$ is the number of alcoholics, and $Y_{2}$ is the total population. They used a low and a high estimate for the number of alcoholics: the low estimate (350700) was taken from data on the prevalence of alcoholism in general practice, ${ }^{6}$ and the high estimate $(600000)$ was taken from a study by Donnan and Haskey on alcoholism and cirrhosis of the liver ${ }^{7}$ that was based on the method of Schmidt and de Lint. ${ }^{8}$ The prevalence of disease among alcoholics was taken from a follow up study of people with a diagnosis of alcoholism discharged from mental hospitals. ${ }^{9}$

McDonnell and Maynard used these estimates to calculate the proportion of deaths that are related to alcohol within selected diagnoses. The resulting numbers were summed to give the estimate of 5000-8000 premature deaths related to alcohol. The range is based on the low and high estimates of the number of alcoholics used by Holtermann and Birchell. As it is based on an "alcoholic" population

\section{Introduction}

determined in the early 1970 s it is likely to be an underestimate.

A report of the Royal College of Physicians gives a figure of 25000 deaths a year related to alcohol, ${ }^{1}$ based on a Swedish study of 8000 men in Malmö aged 46-48 who were followed up for three and a half to eight years. ${ }^{10}$ During the follow up 218 died; $83 \%$ of these underwent necropsy, and one quarter of the deaths were found to be related to alcohol. If this rate is applied to men aged 35-64 in England and Wales the estimated number of deaths associated with alcohol is 17000.

The Royal College of General Practitioners gives a figure of 40000 excess deaths for adults (age 15 or over) in England and Wales. ${ }^{3}$ The figure was calculated by attributing a proportion of deaths within selected diagnoses to alcohol and then summing these deaths. The proportions of deaths were taken from several different studies.

\section{An alternative method}

I devised an alternative method for calculating excess mortality due to alcohol consumption based on that used by the Royal College of Physicians in calculating the excess mortality associated with cigarette smoking. ${ }^{11}$ Four types of information are used: the population of England and Wales by age and sex (table I $)^{12}$; the distribution of alcohol consumption in England and Wales by age and sex (table II) ${ }^{13}$; the total number of deaths in England and Wales by age and sex (table III) ${ }^{14}$; and data from follow up studies. Five follow up studies were used.

TABLE II - Distribution of alcohol consumption by age in men and women. Numbers are percentages; data are for England and Wales in 1978

\begin{tabular}{lrrrrrrrr}
\hline $\begin{array}{l}\text { Units of alcohol } \\
\text { consumed }\end{array}$ & \multicolumn{3}{c}{ Men } & & \multicolumn{3}{c}{ Women } \\
\cline { 2 - 4 } \cline { 7 - 9 } per week & $18-34$ & $35-64$ & $\geqslant 65$ & & $18-34$ & $35-64$ & $\geqslant 65$ \\
\hline 0 & 4 & 6 & 9 & & 4 & 42 & 24 \\
$1-10$ & 37 & 53 & 67 & & 74 & 45 & 70 \\
$11-35$ & 38 & 28 & 21 & & 19 & 12 & 6 \\
$\geqslant 36$ & 21 & 13 & 3 & & 3 & 1 &
\end{tabular}

The Honolulu heart study was a study of cardiovascular disease in men of Japanese descent living in Hawaii: 8006 men aged 45-65 were recruited during 1965-8 and followed up for eight years. ${ }^{15}$ The quantity and frequency of alcohol consumption were measured and validated by 24 hour dietary recall. Death rates were adjusted by the direct method to represent the age structure (in five year groups) of the entire population. Multivariate analysis controlled for cigarette smoking, weight, systolic blood pressure, and serum cholesterol concentration; these factors made little difference to the association of alcohol intake with mortality.

The United Kingdom study of male civil servants recruited 1422 men aged 40-64 in London in 1967-9 and followed them up for 10 years. ${ }^{16}$ Their alcohol consumption was obtained from a three day dietary record. Death rates were standardised for age of the total population by the direct method. Adjustment of these rates for smoking habit, diastolic blood pressure, plasma cholesterol concentration, and grade of employment made little difference to the relative risk of death according to alcohol consumption.

The Kaiser-Permanente study divided 8060 people 
(aged 15-79) according to alcohol consumption into four groups matched for age, sex, race, and cigarette smoking. ${ }^{17}$ They had been recruited from multiphasic health examinations in California and were followed up for 10 years. Alcohol consumption was measured by the number of drinks of specific beverages per day over the previous year. Data were reported separately by sex, age, and smoking habit.

The Chicago Western electric study was a study of coronary heart disease in 1832 men employed by the Western Electric Company. ${ }^{18}$ They were aged 40-55 and free of coronary heart disease and were followed up for 17 years. The number of drinks of specific beverages per month was determined. Death rates

TABLE IV - Mortality and alcohol consumption among men

\begin{tabular}{|c|c|c|c|c|}
\hline & \multicolumn{4}{|c|}{ Units of alcohol consumed/week } \\
\hline & 0 & $1-10$ & $11-35$ & $\geqslant 36$ \\
\hline $\begin{array}{l}\text { Civil servant study: } \\
\text { Population at risk } \\
\text { No of deaths } \\
\text { Annual average death rate/1000 over } 10 \text { years } \\
95 \% \text { Confidence interval }\end{array}$ & $\begin{array}{c}477 \\
45 \\
9 \cdot 4 \\
6 \cdot 8 \text { to } 12 \cdot 1\end{array}$ & $\begin{array}{c}390 \\
24 \\
6 \cdot 2 \\
3 \cdot 8 \text { to } 8 \cdot 5\end{array}$ & $\begin{array}{c}367 \\
24 \\
6 \cdot 5 \\
4 \cdot 0 \text { to } 9 \cdot 1\end{array}$ & $\begin{array}{c}188 \\
20 \\
10 \cdot 6 \\
6 \cdot 2 \text { to } 15 \cdot 1\end{array}$ \\
\hline $\begin{array}{l}\text { Kaiser-Permanente study: } \\
\text { Population at risk } \\
\text { No of deaths } \\
\text { Annual average death rate/1000 over } 10 \text { years } \\
95 \% \text { Confidence interval }\end{array}$ & $\begin{array}{c}1584 \\
157 \\
9 \cdot 9 \\
8 \cdot 4 \text { to } 11 \cdot 4\end{array}$ & $\begin{array}{c}1584 \\
109 \\
6 \cdot 9 \\
5 \cdot 6 \text { to } 8 \cdot 1\end{array}$ & $\begin{array}{c}1584 \\
158 \\
10 \cdot 0 \\
8 \cdot 5 \text { to } 11 \cdot 5\end{array}$ & $\begin{array}{c}1584 \\
227 \\
14 \cdot 3 \\
12 \cdot 6 \text { to } 16 \cdot 1\end{array}$ \\
\hline $\begin{array}{l}\text { Chicago Western Electric study: } \\
\text { Population at risk } \\
\text { No of deaths } \\
\text { Annual average death rate/ } 1000 \text { over } 17 \text { years } \\
95 \% \text { Confidence interval }\end{array}$ & $\begin{array}{c}632 \\
96 \\
8 \cdot 9 \\
7 \cdot 3 \text { to } 10 \cdot 6\end{array}$ & $\begin{array}{c}542 \\
77 \\
8 \cdot 5 \\
6 \cdot 7 \text { to } 10 \cdot 2\end{array}$ & $\begin{array}{c}580 \\
91 \\
9 \cdot 2 \\
7 \cdot 5 \text { to } 11 \cdot 0\end{array}$ & $\begin{array}{c}78 \\
32 \\
24 \cdot 1 \\
17 \cdot 7 \text { to } 30 \cdot 6\end{array}$ \\
\hline $\begin{array}{l}\text { Honolulu Heart study: } \\
\text { Population at risk } \\
\text { No of deaths } \\
\text { Annual average death rate/ } 1000 \text { over } 8 \text { years } \\
95 \% \text { Confidence interval }\end{array}$ & $\begin{array}{c}3747 \\
264 \\
8 \cdot 8 \\
7 \cdot 8 \text { to } 9 \cdot 8\end{array}$ & $\begin{array}{c}1316 \\
68 \\
6 \cdot 5 \\
5 \cdot 0 \text { to } 8 \cdot 0\end{array}$ & $\begin{array}{c}1593 \\
86 \\
6 \cdot 7 \\
5 \cdot 4 \text { to } 8 \cdot 1\end{array}$ & $\begin{array}{c}1232 \\
93 \\
9 \cdot 4 \\
7 \cdot 6 \text { to } 11 \cdot 3\end{array}$ \\
\hline $\begin{array}{l}\text { Framingham study: } \\
\text { Population at risk } \\
\text { No of deaths } \\
\text { Annual average death rate/ } 1000 \text { over } 22 \text { years } \\
95 \% \text { Confidence interval }\end{array}$ & $\begin{array}{c}402 \\
155 \\
17 \cdot 5 \\
15 \cdot 4 \text { to } 19 \cdot 7\end{array}$ & $\begin{array}{c}668 \\
179 \\
12 \cdot 2 \\
10 \cdot 7 \text { to } 13 \cdot 7\end{array}$ & $\begin{array}{c}783 \\
215 \\
12 \cdot 5 \\
11 \cdot 1 \text { to } 13 \cdot 9\end{array}$ & $\begin{array}{c}253 \\
97 \\
17 \cdot 3 \\
14 \cdot 6 \text { to } 20 \cdot 0\end{array}$ \\
\hline
\end{tabular}

TABLE V - Mortality and alcohol consumption among women

\begin{tabular}{|c|c|c|c|c|}
\hline & \multicolumn{4}{|c|}{ Units of alcohol consumed/week } \\
\hline & $\mathbf{0}$ & $1-10$ & $11-35$ & $\geqslant 36$ \\
\hline $\begin{array}{l}\text { Kaiser-Permanente study: } \\
\text { Population at risk } \\
\text { No of deaths } \\
\text { Annual average death rate/1000 over } 10 \text { years } \\
95 \% \text { Confidence intervals }\end{array}$ & $\begin{array}{c}431 \\
19 \\
4 \cdot 4 \\
2 \cdot 5 \text { to } 6 \cdot 4\end{array}$ & $\begin{array}{c}431 \\
16 \\
3 \cdot 7 \\
1 \cdot 9 \text { to } 5 \cdot 5\end{array}$ & $\begin{array}{c}431 \\
28 \\
6 \cdot 5 \\
4 \cdot 2 \text { to } 8 \cdot 8\end{array}$ & $\begin{array}{c}431 \\
28 \\
6 \cdot 5 \\
4 \cdot 2 \text { to } 8 \cdot 8\end{array}$ \\
\hline $\begin{array}{l}\text { Framingham study: } \\
\text { Population at risk } \\
\text { No of deaths } \\
\text { Annual average death rate/ } 1000 \text { over } 22 \text { years } \\
95 \% \text { Confidence interval }\end{array}$ & $\begin{array}{c}1079 \\
240 \\
10 \cdot 1 \\
9 \cdot 0 \text { to } 11 \cdot 2\end{array}$ & $\begin{array}{c}1041 \\
182 \\
7 \cdot 9 \\
6 \cdot 9 \text { to } 9 \cdot 0\end{array}$ & $\begin{array}{c}456 \\
86 \\
8 \cdot 6 \\
6 \cdot 9 \text { to } 10 \cdot 2\end{array}$ & $\begin{array}{c}65 \\
13 \\
9 \cdot 1 \\
4 \cdot 7 \text { to } 13 \cdot 5\end{array}$ \\
\hline
\end{tabular}

TABLE VI - Deaths of men aged 35-64 in England and Wales related to alcohol consumption and calculated from death rates in civil servants ${ }^{16}$

\begin{tabular}{lccc}
\hline $\begin{array}{l}\text { Consumption } \\
\text { band } \\
\text { (units/week) }\end{array}$ & $\begin{array}{c}\text { No of men } \\
\text { (millions) }\end{array}$ & Deaths/1000 & No of deaths \\
\hline 0 & $0 \cdot 49$ & $9 \cdot 4$ & 4606 \\
$1-10$ & $4 \cdot 29$ & $6 \cdot 2$ & 26598 \\
$11-35$ & $2 \cdot 27$ & $6 \cdot 5$ & 14755 \\
$\geqslant 36$. & $1 \cdot 05$ & $10 \cdot 6$ & 11130 \\
\hline Total population & $8 \cdot 1$ & & 57803 \\
\hline
\end{tabular}

TABLE VII - Estimates of excess deaths due to alcohol consumption among men aged 35-64 in England and Wales

\begin{tabular}{lcccc}
\hline & $\begin{array}{c}\text { Duration of } \\
\text { follow up } \\
\text { (years) }\end{array}$ & Sample size & $\begin{array}{c}\text { Estimate of } \\
\text { excess deaths }\end{array}$ & $\begin{array}{c}\text { 95\% Confidence } \\
\text { interval }\end{array}$ \\
\hline Honolulu heart study & 8 & 8006 & 4462 & 3807 to 5463 \\
Civil servant study & 10 & 1422 & 6645 & 6019 to 6875 \\
Kaiser-Permanente study & 10 & 6336 & 13909 & 12863 to 15341 \\
Chicago Western Electric study & 17 & 1832 & 14117 & 13164 to 14729 \\
Framingham study & 22 & 2106 & 3806 & 3640 to 3934 \\
\hline
\end{tabular}

TABLE VIII - Estimates of excess deaths due to alcohol consumption among women aged 35-64 in England and Wales

\begin{tabular}{lccrcc}
\hline & $\begin{array}{c}\text { Duration of } \\
\text { follow up } \\
\text { period } \\
\text { (years) }\end{array}$ & $\begin{array}{c}\text { Sample } \\
\text { size }\end{array}$ & $\begin{array}{c}\text { Estimate of } \\
\text { excess deaths }\end{array}$ & $\begin{array}{c}95 \% \\
\text { Confidence } \\
\text { interval }\end{array}$ \\
\hline Kaiser-Permanente study & 10 & 1724 & 3375 & 2801 to 4852 \\
Framingham study & 22 & 2641 & 393 & 0 to 761 \\
\hline
\end{tabular}

were adjusted for the age of the total population. Adjustment for diastolic blood pressure, smoking habit and pulse rate made little difference to the relative risk of death according to alcohol consumption.

The Framingham study was a study of cardiovascular disease in 5209 men and women aged 29-62 in Framingham, Massachusetts. ${ }^{19}$ They were first examined in 1948 and were followed up for 17 years. Alcohol consumption was obtained by estimating the average number of drinks of specific beverages per month. Death rates were adjusted for the age of the total population by the direct method. Adjustment for systolic blood pressure, cigarette consumption, relative weight, and serum lipoprotein concentrations made little difference to the relative risk of death according to alcohol consumption. Data were reported separately for men and women.

I converted the alcohol consumption of the different groups in the five studies to units of alcohol consumed per week (one unit contains $8 \mathbf{g}$ of absolute alcohol) and calculated the death rates for men (table IV) and women (table V). As all five studies showed a J shaped relation between alcohol consumption and death (abstainers have higher death rates than those drinking 1-10 units per week) I used a consumption of 1-10 units per week as the baseline measurement and subtracted the excess deaths for abstainers from this figure. For example, to calculate the excess deaths associated with alcohol consumption among men aged 35-64 from the death rates in the study of civil servants I applied the proportions of drinkers found in Wilson's study ${ }^{13}$ (table II) to the total population to give the number of men in England and Wales consuming specified amounts of alcohol. These population figures were multiplied by the death rates calculated from the study of civil servants. ${ }^{16}$ The total number of estimated deaths was 57809 (table VI). The baseline, deaths in the consumption band 1-10 units, was 50220 (death rate multiplied by total population: in this example $6 \cdot 2 / 1000 \times 8.1$ million). The excess deaths for abstainers were 1568 (excess rate of $(9 \cdot 4-6 \cdot 2) / 1000=$ $3 \cdot 2 / 1000$ applied to 0.49 million abstainers); thus the excess mortality was $6021(57809-50220-1568)$. As the actual number of deaths in 1985 among men aged 35-64 in England and Wales was 67529 applying a correction factor of $1 \cdot 16(67529 / 57809)$ gave a total number of excess deaths of 7033 (67 529-(50220 $\times 1 \cdot 168)-(1568 \times 1 \cdot 168)$.

This calculation was made for all five studies. Tables VII and VIII give the estimates of excess deaths derived from the different studies for men and for women, respectively, in the age range 35-64. The 95\% confidence intervals for the estimated excess deaths were based on the $95 \%$ confidence intervals for the rates given in tables IV and V. The data from the Kaiser-Permanente study gave a total number of excess deaths of 28178 - say 28000 - in England and Wales among people aged 15-74 (table IX).

\section{Discussion}

The estimates of the excess mortality associated with alcohol consumption provided in previous studies present several problems. The estimate of McDonnell 
TABLE IX - Estimate of excess deaths due to alcohol consumption in England and Wales by age group (based on Kaiser-Permanente study)

\begin{tabular}{lcc}
\hline Age range (years) & Estimate of excess deaths & $95 \%$ Confidence interval \\
\hline $15-34$ & 3716 & 3281 to 4525 \\
$35-64$ & 17284 & 15664 to 20193 \\
$65-74$ & 7178 & 6232 to 8680 \\
\hline Total population & 28178 & 25177 to 33398 \\
\hline
\end{tabular}

and Maynard was based on data from the early 1970s and on a select group of the population; "alcoholics" discharged from mental hospitals. Alcoholics are likely to contribute only a small proportion of the total excess mortality due to alcohol consumption. ${ }^{20}$ The Royal College of Physicians based its estimate on a Swedish population that is unlikely to be representative of the English and Welsh populations, and data were provided only for middle aged men. The estimate of the Royal College of General Practitioners was based on the total population aged over 15 , whereas most deaths occur in those aged over 75 , when there is great uncertainty over whether death is associated with alcohol consumption.

The estimate presented in this paper is based on methods previously applied to ascertain the association between death and cigarette smoking. ${ }^{11}$ Unfortunately there is no single basic study of the association of death with alcohol consumption so estimates were based on results from one British and four American studies.

The five studies used in my calculations have drawbacks. Firstly, four of the studies were carried out in the United States on populations differing in ethnic origin, social class, and employment state, all of which have independent effects on alcohol consumption and mortality. Data on mortality from these North American studies may not apply to populations in the United Kingdom. Secondly, a cohort phenomenon may limit the applicability of these studies. The risk related to alcohol consumption in populations derived 25 or so years ago may be different from that in current populations with the same alcohol consumption. Thirdly, four of the studies were studies of coronary heart disease; although they included an estimate of alcohol consumption, they were not designed to relate alcohol consumption to mortality. Finally, four of the five studies give little detail about risk for different age groups, providing data only for the range 35-64 years. Only the Kaiser-Permanente study provided adequate data for different age ranges.

An estimate of total excess deaths based on one study should increase the validity of this calculation. Based on the Kaiser-Permanente study the total excess mortality came to 28000 deaths. This is an estimate of the association between alcohol consumption and mortality, not between alcohol consumption and specific diseases. Further longitudinal studies are needed to investigate the association of alcohol consumption with morbidity and mortality.

\footnotetext{
1 Royal College of Physicians. A great and growing evil. London: Tavistock, 1987.

Royal College of Psychiatrists. Alcohol, our favourite drug. London: Tavistock, 1986:x.

Royal College of General Practitioners. Alcohol: a balanced view. London: RCGP, 1986:45.

McDonnell R, Maynard A. Estimation of life years lost from alcohol-related premature death. Alcohol Alcohol 1985;20:435-43.

Holtermann S, Burchell A. The costs of alcohol misuse. London: Department of Health and Social Security, 1981 .

6 Wilkins R. The hidden alcoholic in general practice. London: Elek Science, 1974.

7 Donnan SPB, Haskey J. Alcoholism and cirrhosis of the liver. Population Trends 1977;7:18-24.

8 Schmidt $W$, de Lint J. Estimating the prevalence of alcoholism from alcohol consumption and mortality data. Qf Stud Alcohol 1970;31:957-64

9 Adelstein A, White G. Alcoholism and morbidity. Population Trends 1976;6: 7-13.

10 Petersson B, Trell E, Henningsen N-C, Hood B. Risk factors for premature death in middle aged men. $\mathrm{Br} M e d \mathcal{F}$ 1984;288:1264-8.

11 Royal College of Physicians. Smoking and health now. London: Pitman Medical, 1971.

12 Central Statistical Office. Social trends. London: HMSO, 1987;16:19-21.

13 Wilson P. Drinking in England and Wales. London: HMSO, 1980:10.

14 Office of Population Censuses and Surveys. Deaths by cause, 1984. OPCS Monitor 1985; No 3. (DH2 85/3.)

15 Blackwelder WC, Yano K, Rhodes GG, Kogan A, Gordon T, Palesch Y. Alcohol and mortality: the Honolulu heart study. Am f Med 1980;60:164-9. 16 Marmot MG, Rose G, Shipley NJ, Thomas BJ. Alcohol and mortality: a U-shaped curve. Lancet 1981;i:580-2.

17 Klatsky AL, Friedman GD, Siegelaub AB. Alcohol and mortality: a ten-year Kaiser-Permanente experience. Ann Intern Med 1981;95:139-45.

18 Dyer AR, Stamler J, Paul O, et al. Alcohol consumption and 17-year mortality in the Chicago Western Electric Company study. Prev Med 1980;9:78-90. 9 Gordon T, Kannel WB. Drinking and mortality. Am $\mathcal{F}$ Epidemiol 1984;120: 97-107.

20 Kreitman N. Alcohol consumption and the preventive paradox. $\mathrm{Br} \mathcal{F}$ Addict 1986;81:353-63.
}

(Accepted 3 fune 1988)

\section{Postmarketing surveillance of enalapril. I: Results of prescription-event monitoring}

Drug Safety Research Unit, Botley, Southampton William H W Inman, FRCP, director and professor of pharmacoepidemiology Nigel S B Rawson, PHD, principal research officer Lynda V Wilton, PHD, senior research officer

Gillian L Pearce, BSC, senior technical officer

\section{Department of Clinical} Pharmacology, Royal Postgraduate Medical School, London W12 0NN Christopher J Speirs, MRCP, lecturer in clinical toxicology

Correspondence and requests for reprints to Professor W H W Inman, Drug Safety Research Unit, North Croft House,

Winchester Road, Botley, Southampton SO3 2BX.

\section{William H W Inman, Nigel S B Rawson, Lynda V Wilton, Gillian L Pearce, Christopher J Speirs}

\section{Abstract}

To identify and measure the incidence of adverse effects of the angiotensin converting enzyme inhibitor enalapril 13713 patients were studied for one year by prescription-event monitoring. Precise information about the duration of treatment was available for 12543 patients. The frequency of many events was calculated, including dizziness $(483$ patients; $3.9 \%)$, persistent dry cough $(360 ; 2.9 \%)$, headache $(310 ; 2.5 \%)$ hypotension $(218 ; 1.7 \%)$, and syncope $(155 ; 1 \cdot 2 \%)$. Less common reactions included angioedema, urticaria, and muscle cramps. Altogether $1098(8 \%)$ patients died and the notes of 913 of them $(83 \%)$ were obtained for detailed scrutiny. With the exception of a few patients with renal failure who deteriorated during treatment (reported on separately), no death was attributed to enalapril. Enalapril was considered to be effective, even in patients with advanced cardiac failure.

These results for enalapril are reassuring and provide further evidence of the value of prescriptionevent monitoring.

\section{Introduction}

The angiotensin-converting enzyme inhibitor enalapril maleate was first marketed in general practice in the United Kingdom in April 1985. Arrangements were made immediately to conduct postmarketing surveillance by prescription-event monitoring, which has been developed by the Drug Safety Research Unit. The purpose of prescription-event monitoring is to identify and measure adverse effects of new drugs soon after their introduction into general practice.

\section{Patients and methods}

The method has been described elsewhere. ' Briefly, prescription-event monitoring uses copies of NHS prescriptions as a means of identifying a patient, a 